\title{
Naringin: Biosynthesis and Pharmaceutical Applications
}

\author{
PRIYA SHARMA, V. KUMAR ${ }^{1}$ AND P. GULERIA* \\ Plant Biotechnology \& Genetic Engineering Lab, Dept of Biotechnology, DAV University, Jalandhar, Punjab-144 012, ${ }^{1}$ Department \\ of Biotechnology, School of Bioengineering and Biosciences, Lovely Professional University, Phagwara, Punjab-141 114, India
}

\section{Sharma et al.: Biosynthesis and Pharmaceutical Applications of naringin}

\begin{abstract}
Naringin is a plant flavonoid of huge medicinal importance. It is synthesized by the phenylpropanoid pathway via seven enzyme catalysed steps from phenylalanine to prunin. The genes encoding the enzymes of phenylpropanoid pathway have been cloned and characterized. Naringin has been known to possess antioxidant, antiinflammatory and antitumer potential. Exposure to naringin in vivo and in vitro in several test animals and cell lines has been reported to demonstrate activities that could treat asthma, hyperlipidaemia, diabetes, tumour, hyperthyroidism and osteoclastogenesis. Based on the reported research of naringin on test animals, naringin could be regarded as an efficient natural remedy for the treatment of human metabolic disorders. However, detailed exploration of naringin exposure on humans needs to be studied.
\end{abstract}

Key words: Naringin, phenylpropanoid pathway, medical applications, health, nutrition

Naringin is a plant flavonoid of great human value. Flavonoids are ubiquitous polyphenolic secondary metabolites isolated from vascular plants ${ }^{[1]}$. They have a general structure of 15 -carbon skeleton that contains two phenyl rings $\mathrm{A}, \mathrm{B}$ and a heterocyclic ring $\mathrm{C}^{[2]}$. Flavonols are the most important flavonoids participating in the stress responses of plants ${ }^{[3]}$. Approximately 8000 flavonoids have been identified from various citrus fruits, vegetables and beverages ${ }^{[4]}$. They behave as chemical messengers, pollinator attractants and stress regulatory elements of plants ${ }^{[5]}$. Flavonoids also exhibit human health promoting abilities like antioxidant and free radical scavenging potential ${ }^{[6]}$. They act as antiviral, antibacterial, antiinflammatory, vasodilatory, anticancer and antiischemic agents ${ }^{[7-12]}$. Flavonoids can undergo various metabolic transformations such and hence their biological activities ${ }^{[13]}$.

\section{ACCUMULATION OF FLAVONOIDS}

The biosynthesis and accumulation of flavonoids is site-specific. Flavonoids are localized in the nucleus, vacuole, cell wall, cell membrane and cytoplasm of the plant cells ${ }^{[14-16]}$. Further, the site specificity of flavonoids in plants is related to their typical physiological, biochemical or morphological traits. The alfalfa seeds have been reported to possess quercetin, luteolin and 7,4'-dihydroxyflavone flavonoids. The stem and roots, however accumulated as methylation and sulfation to change their structures

isoflavonoids, medicarpin 3-O-glucoside-6-Omalonate, formononetin 7-O-glucoside-6"-O-malonate and coumestrol glycosides ${ }^{[14]}$. The Betula pendula and B. resinifera plants originating from Finland, Germany and Alaska have also been reported to accumulate flavonoids, condensed tannins and hydroxycinnamic acid only in the leaves on exposure of UV-B radiations. However, the plants belonging to Alaska showed highest flavonoid accumulation ${ }^{[15]}$. Likewise, various forms of soluble flavonoids are predominantly present in grape seeds, white clover and fruit berries. A detailed description of accumulation and transport of distinct flavonoids of grapevine has already been extensively discussed $^{[16-18]}$. Hence, flavonoids are ubiquitous but site specific in nature.

\section{NARINGIN}

Naringin is an important water soluble flavonoid isolated from the citrus fruits ${ }^{[19]}$. It has a molecular weight of $580.4 \mathrm{~g} / \mathrm{mol}$ and molecular formula is $\mathrm{C}_{27} \mathrm{H}_{23} \mathrm{O}_{14}$ (fig. 1). It has antioxidant potential and plays an important role in the development of leaves, flowers,

This is an open access article distributed under the terms of the Creative Commons Attribution-NonCommercial-ShareAlike 3.0 License, which allows others to remix, tweak, and build upon the work non-commercially, as long as the author is credited and the new creations are licensed under the identical terms

Accepted 10 September 2019

Revised 11 May 2019

Received 08 January 2019

*Address for correspondence

E-mail: pvihbt@gmail.com

November-December 2019

Indian Journal of Pharmaceutical Sciences 




Fig. 1: Molecular structure of naringin

Naringin has a molecular weight of $580.4 \mathrm{~g} / \mathrm{mol}$ and a molecular formula of $\mathrm{C}_{27} \mathrm{H}_{23} \mathrm{O}_{14}$. It is a water soluble antioxidant compound

buds and fruits of plants. It has further induces bitterness to the fruits as in grape fruit. However, the bitterness can be reduced upon reduction by the enzyme naringinase ${ }^{[20]}$.

\section{Naringin biosynthesis via phenylpropanoid pathway:}

The phenylpropanoid pathway begins with phenylalanine, an end product of shikimate pathway. The phenylpropanoid pathway gives rise to a diversity of end products ranging from flavonoids, tannins and lignins ${ }^{[21]}$. The description of phenylpropanoid pathway is discussed hereafter.

The first 7 enzyme catalysed steps of phenylproponoid biosynthesis pathway leads to naringin synthesis (fig. 2). The first step catalyses the conversion of phenylalanine into cinnamic acid by enzyme phenylalanine ammonia-lyase (PAL). Phenylalanine is deaminated to cinnamic acid and ammonia. In the second step, cinnamate 4-hydroxylase $(\mathrm{C} 4 \mathrm{H})$ catalyses conversion of cinnamic acid into p-coumarate. p-Coumarate is later metabolised into $\mathrm{p}$-coumaroyl $\mathrm{CoA}$ via enzyme 4-coumarate CoA-ligase (4CL) ${ }^{[22]}$. The pathway up to p-coumaroyl CoA synthesis is general phenylpropanoid pathway. Subsequently, the pathway diversifies into isoflavonoids, stilbenes, proanthocyanidins, flavonols and anthocyanins ${ }^{[23]}$. The enzymes chalcone synthase (CHS) and chalcone isomerase (CHI) catalyse the division of phenylpropanoids into flavonoid biosynthesis. Further, uridine diphosphoglucoseflavanone 7-O-glucotransferase (UF7GT) mediated catalysis generates a group of diverse metabolites ${ }^{[23]}$.

\section{CHARACTERIZATION OF ENZYMES INVOLVED IN NARINGIN BIOSYNTHESIS}

\section{Phenylalanine ammonia-lyase $(P A L)$ :}

The $P A L$ gene encoding enzyme has been isolated from a wide range of plant species. In Epimedium, EsPAL was reported to significantly regulate the metabolite flux of phenylpropanoid pathway for the biosynthesis of various metabolites including icariin, epimedin A, $\mathrm{B}$ and $\mathrm{C}^{[24]}$. SsPAL1 from ornamental plant Coleus, Solenostemon scutellarioides was characterized to be stress responsive because of the presence of cisacting elements ${ }^{[25]}$. The $P A L$ gene has also isolated and sequenced from three Buckwheat species, Fagopyrum tataricum, $F$. esculentum and $F$. dibotrys ${ }^{[26]}$. A biotic stress responsive 2145 bp long $H b P A L$ has also been characterized from rubber ${ }^{[27]}$. Similarly, $P A L$ has been reported to be cloned and characterized from various plants including Salix, Capsicum, Musa acuminate and rice $^{[28-31]}$. Like higher eukaryotes, 2114 bp long TcPAL has also been characterized from yeast Trichosporon cutaneum $^{[32]}$. Hyun et al. describes various $P A L$ genes isolated and characterized from plants and fungi[33].

\section{Cinnamic acid 4-hydroxylase $(\mathrm{C} 4 \mathrm{H})$ :}

$\mathrm{C} 4 \mathrm{H}$ belongs to the $\mathrm{P} 450$ monooxygenase super family localized in the endoplasmic reticulum of plants ${ }^{[34]}$. It is involved in the detoxification of herbicides as well as pesticides ${ }^{[35]}$. Most recently, BnGC4H gene has been characterized from ramie (Boehmeria nivea) to be strongly expressed in mature xylem suggesting its role in lignin biosynthesis ${ }^{[36]}$. Likewise, abiotic stress responsive $\mathrm{GbC4H}$ isolated from Ginkgo biloba was characterized to possess recognition sites for stress responsive transcription factors GT-1, WRKY transcription factor and myeloblastosis family transcription factor/Myc ${ }^{[37]}$. Recently, $\mathrm{PaC} 4 \mathrm{H}$, $\mathrm{MpC} 4 \mathrm{H1}$ and $\mathrm{MpC} 4 \mathrm{H} 2$ showing catalytic activity towards trans-cinnamic acid have been isolated from bryophytes, Plagiochasma appendiculatum and Marchantia paleacea, respectively ${ }^{[38]}$. Abiotic stress inducible $\mathrm{C} 4 \mathrm{H}$ genes have also been characterized from tea and sweet potato ${ }^{[39,40]}$. Similarly, $C 4 H$ gene 


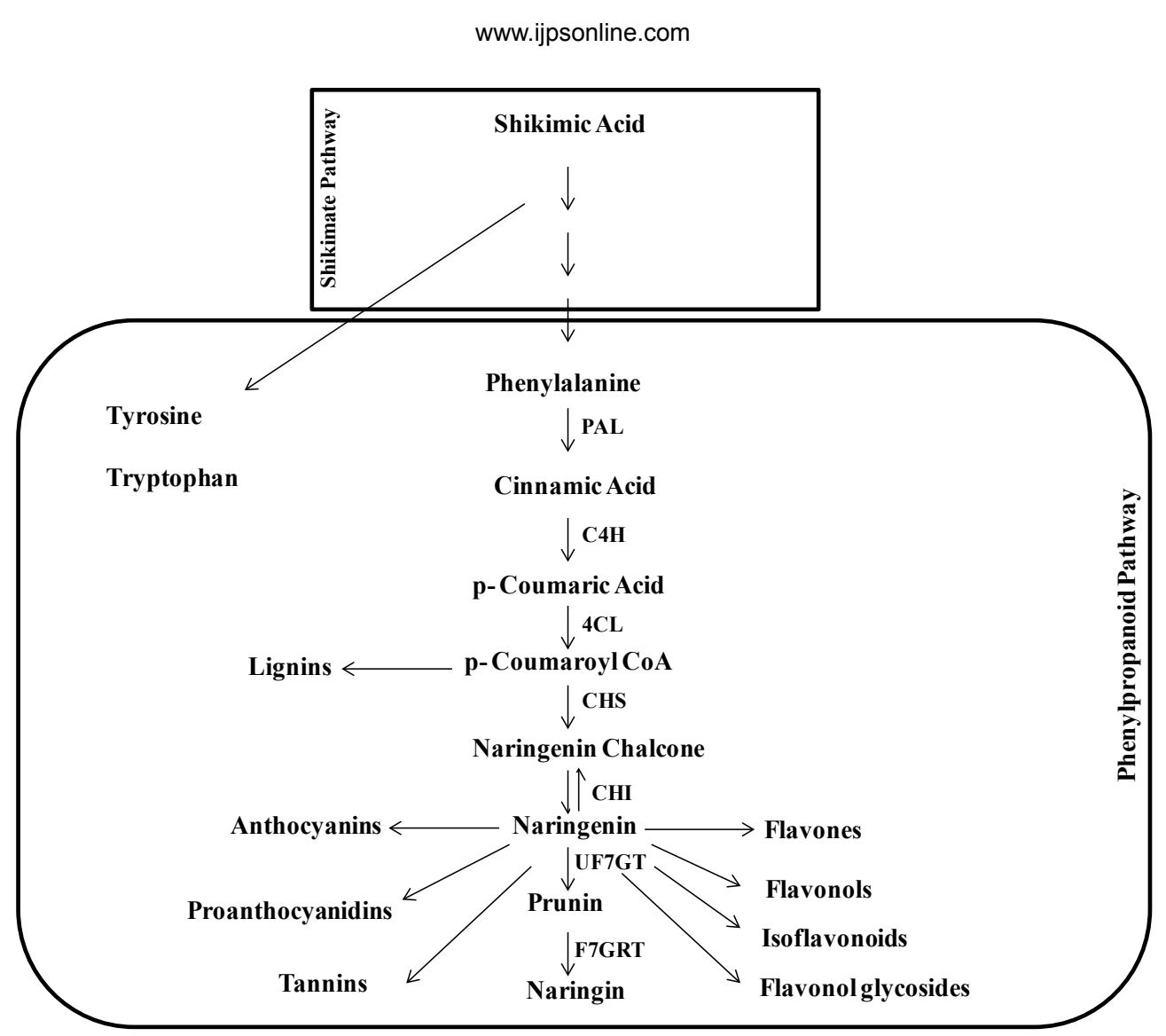

Fig. 2: Brief overview of phenylpropanoid biosynthesis pathway

The shikimate pathway leads to the synthesis of phenylalanine that acts as starting molecule of the phenylpropanoid biosynthesis pathway. Phenylalanine is metabolized into naringin via 7 enzyme-catalysed steps. The enzymes abbreviated as $P A L, C 4 H, 4 C L$, $C H S, C H I, U F 7 G T$ and $F 7 G R T$ stands for phenylalanine ammonia lyase, cinnamate-4 hydroxylase, 4-coumaroyl: CoA-ligase, chalcone synthase, chalcone isomerase, uridine diphosphoglucose-flavanone 7-O-glucosyltransferase and flavanone 7-O-glucoside 2-O-beta-L-rhamnosyltransferase, respectively

has been isolated and characterized from several plant species $^{[11,42]}$.

\section{4-coumaroyl: CoA-ligase ( $4 C L)$ :}

The $4 C L$ mediated catalysis is the last crucial step of phenylpropanoid metabolism ${ }^{[22]}$. The $4 C L$ gene has been characterized from various plants ${ }^{[43,44]}$. The cytosol specific putative four $4 C L$ genes has been reported from Peucedanum praeruptorum, out of which only Pp4CL1 showed root specific catalytic activity for p-coumaric acid ${ }^{[45]}$. A $4 C L$ homolog Pa4CL1 from liverwort Plagiochasma appendiculatum was characterized to possess 4-coumaroyl: CoA-ligase activity in $E$. coli ${ }^{[46]}$. The $4 C L$ isoform homologues 4CL1-4CL4 characterized from Arabidopsis thaliana showed phylogenetic closeness but distinct functionality. The $4 C L 1$ showed significant role in lignin biosynthesis while $4 C L 3$ was responsible for flavonoids biosynthesis ${ }^{[47]}$.

\section{Chalcone synthase (CHS):}

CHS is the first regulatory enzyme as it diverts phenylpropanoid to diverse flavonoid biosynthesis ${ }^{[48]}$. Five stress responsive MaCHS genes isolated from cytoplasmic fractions of mulberry has revealed the abundant accumulation of MaCHS1, MaCHS2 in fruits, MaCHS3, MaCHS5 in old leaves and MaCHS4 in root $\operatorname{bark}^{[48]}$. Likewise, environmental stress responsive $\mathrm{NtCHS}$ genes has also been characterized from vegetative and floral tissues of tobacco ${ }^{[49,50]}$. The MdCHS isolated from apple was validated for polyketide synthase activity leading to the synthesis of phloretin, naringenin chalcone, and pinocembrin chalcone ${ }^{[48]}$. The functional validation of SoCHS isolated from Syringa oblate in tobacco has identified it as flavonoid metabolism regulator ${ }^{[51]}$. Several reports of $C H S$ characterization from plants have been documented ${ }^{[52,53]}$.

\section{Chalcone isomerase $(\mathrm{CHI})$ :}

CHI importantly regulates the intramolecular stereospecific cyclization of chalcones into (S)-flavanones. The characterization of $\mathrm{CHI}$ from various plant species has been reported ${ }^{[54,55]}$. The 
DaCHI1 isolated from Deschampsia antarctica has shown enhanced substrate specificity for naringenin chalcone than isoliquiritigenin. The multi-substrate acting potential of DaCHII facilitated flavonoids production during oxidative stress and environmental variability ${ }^{[56]}$. The $\mathrm{CHI}$ gene isolated from Chinese water chest nut was characterized for maximum activity at $45^{\circ}$ and $\mathrm{pH} 7.5$ in presence of $\mathrm{Ca}^{2+}$ and $\mathrm{Cu}^{2+[57]}$. The characterization of SlCHII from wild tomato has revealed a probable metabolic link with terpenoid biosynthesis ${ }^{[58]}$. Similarly, snapdragon $\mathrm{AmCHI} 1$ was characterized to regulate the metabolite flux of flavonoids biosynthesis towards aurone and non-aurone flavonoids ${ }^{[59,60]}$.

\section{Uridine diphosphate-sugar dependent glycosyltransferases $(U G T s)$ :}

Flavonoids constitute a variety of aglycone and glycone derivatives catalysed by UGTS. The UGTs either code for flavonoid glucosyltransferase and/or rhamnosyltransferase in support of phenylpropanoid pathway ${ }^{[61]}$. The metabolic conversion of naringenin to naringin occurs via two UGTS catalysed steps. The involved probable $U G T S$ are Uridine diphosphoglucose-flavanone 7-O-glucosyltransferase (UF7GT) and flavanone 7-O-glucoside 2-O-betaL-rhamnosyltransferase $(F 7 G R T)$. Recently, $U G T$ flavonoid glycosyltranserase (UFGT) isolated from sweet orange was characterized for flavonoid 7-O-glucosyltransferase and 7-O-rhamnosyltransferase activities to metabolize substrates including naringenin, hesperetin, kaempferol and quercetin ${ }^{[62]}$. Likewise, UFGTs from Freesia hybrida and Crocus sativus were characterized for 3GT activity in $A$. thaliana ${ }^{[63,64]}$.

\section{THERAPEUTIC POTENTIALOFNARINGIN}

Naringin appeared to possess diverse activities such as antioxidant, antiinflammatory, anticancer and antiapoptotic ${ }^{[65]}$. Its pharmacological effects have been well validated through in vitro and in vivo animal studies. However, its effect on human health is still unknown ${ }^{[66]}$. The various therapeutic applications of naringin are described hereafter (Table 1).

\section{Effect of naringin on ischemic reperfusion injury of animals:}

Ischemia is a common means of inducing mortality to animals. Ischemia followed by reperfusion and presence of oxygen-derived free radicals known as reactive oxygen species (ROS) leads to animal mortality.
Hence, nutritional and pharmaceutical-based therapies are investigated to regulate the free radical mediated damage ${ }^{[67]}$. Naringin has been reported to effectively regulate the ischemic reperfusion mediated neurological alteration in the cortex, striatum and hippocampus brain regions of male Wistar rats on exposure of 50 and $100 \mathrm{mg} / \mathrm{kg}$ dosage by enhancing their ROS scavenging potential ${ }^{[68]}$. Naringin was documented to cross bloodbrain barrier and scavenge peroxynitrite-induced mitophagy in human neural SH-SY5Y cells ${ }^{[69]}$. The antioxidant potential of naringin alleviated the ischemic reperfusion-induced renal damage at $400 \mathrm{mg} / \mathrm{kg}$ exposure $^{[70]}$. Likewise, protective effect of naringin against mesenteric ischemia in rats at exposure of $80 \mathrm{mg} / \mathrm{kg}$ dose was reported ${ }^{[71]}$. Isoproterenol-mediated myocardial ischemia symptomized by reduced activity of mitochondrial antioxidant enzymes was alleviated on pre-naringin treatment ${ }^{[72,73]}$. Similarly, $400 \mathrm{mg} / \mathrm{kg}$ naringin regulated the skeletal muscle ischemia/ damage of male Sprague Dawley rats ${ }^{[74]}$.

\section{Naringin and cancer cells:}

The antitumor potential of naringin in animal cells including human cell lines has been documented. Naringin inhibited the $\beta$-catenin signalling pathway of human derived triple-negative (ER-/PR-/HER2-) breast cancer (TNBC) cells and arrested the cell proliferation in the G1 phase of cell cycle followed by cellular apoptosis ${ }^{[75]}$. Likewise, naringin activated Ras/Raf/ERK pathways for enhanced p21WAF1 expression to arrest proliferation and induce apoptosis of human bladder carcinoma 5637 cell line ${ }^{[76]}$. In vivo intraperitoneal administration of naringin reduced TNF- $\alpha$ and IL- 6 accumulation to inhibit the tumorous growth in rats bearing walker 256 carcinosarcoma ${ }^{[77]}$. Ganglioside-mediated anticancer potential of naringin has also been reported. Naringin inhibited glycosidase NEU3 to enhance GM3 gangliosides that inhibited proliferation of HeLa and A549 cell lines ${ }^{[78]}$. Likewise, naringin regulated the proliferation of HepG2 hepatocellular carcinoma cell line ${ }^{[79]}$. Further, naringinbased synthetic ruthenium complex showed anticancer potential against A549 human cell line without any toxicity on dermal fibroblasts ${ }^{[80]}$.

\section{Effects of naringin on metabolic syndrome:}

Collective occurrence of genetic and environmentinduced physiological, biochemical and metabolic variations designates metabolic syndrome. These are generally associated with glucose intolerance, insulin resistance, increased blood pressure, atherogenic 
TABLE 1: MEDICINAL APPLICATIONS OF NARINGIN

\begin{tabular}{|c|c|c|c|c|}
\hline Medical condition & Animal exposed & Mode of delivery & Observed Alteration & Reference \\
\hline & Male Wistar rats & $\begin{array}{c}\text { Intraperitoneal } \\
\text { administration for seven } \\
\text { days }\end{array}$ & $\begin{array}{l}\text { Improved neurobehavioral alterations, } \\
\text { debilitating oxidative damage }\end{array}$ & [69] \\
\hline \multirow[t]{4}{*}{$\begin{array}{l}\text { Ischemic } \\
\text { reperfusion }\end{array}$} & Rats & $\begin{array}{l}\text { Administered as suspension } \\
\text { in physiological saline }\end{array}$ & Renopotective effect & [71] \\
\hline & Rats & Intraperitoneal infusion & Lowered oxidative stress markers and injury score & [72] \\
\hline & $\begin{array}{l}\text { Male Sprague } \\
\text { Dawley rats }\end{array}$ & Oral administration & $\begin{array}{l}\text { Lowered GSH-Px level, decreased SOD and CAT } \\
\text { activity of muscles, higher plasma level of CK }\end{array}$ & [75] \\
\hline & Male Wistar rats & $\begin{array}{l}\text { Intraperitoneal } \\
\text { administration }\end{array}$ & $\begin{array}{c}\text { Inhibited tumor growth, increased survival rate } \\
\text { and reduced TNF- } \alpha \text { and IL- } 6 \text { levels }\end{array}$ & [78] \\
\hline \multirow[t]{6}{*}{ Cancer cells } & $\begin{array}{l}\text { Rats bearing } \\
\text { walker } 256 \\
\text { carcinosarcoma }\end{array}$ & $\begin{array}{l}\text { Intraperitoneal } \\
\text { administration }\end{array}$ & $\begin{array}{l}\text { Inhibited tumor growth and reduced levels of } \\
\text { TNF-a and IL-6, enhanced survival rate of rats }\end{array}$ & [78] \\
\hline & $\begin{array}{l}\text { HeLa, A549 } \\
\text { cancer cell lines }\end{array}$ & $\begin{array}{l}\text { Exposed to cells in mixture } \\
\text { with DMSO }\end{array}$ & $\begin{array}{c}\text { Suppressed growth of cell lines and NEU3 } \\
\text { glycosidase degrading GM3 ganglioside. Increased } \\
\text { GM3 ganglioside. Downregulation of Epidermal } \\
\text { Growth Factor Receptor and extracellular signal- } \\
\text { regulated kinases phosphorylation }\end{array}$ & [79] \\
\hline & $\begin{array}{l}\text { High fat diet fed } \\
\text { Rats }\end{array}$ & Oral administration & $\begin{array}{c}\text { Normalised systolic blood pressure and } \\
\text { improved vascular dysfunction and ventricular } \\
\text { diastolic dysfunction }\end{array}$ & [92] \\
\hline & Rats & $\begin{array}{l}\text { Orally using an intragastric } \\
\text { tube }\end{array}$ & $\begin{array}{c}\text { Decreased total ester and free cholesterol } \\
\text { level, TG, FFA in serum and heart. Reduced } \\
\text { alteration of serum lipoprotein and lipid } \\
\text { metabolic enzymes. }\end{array}$ & [73] \\
\hline & Male Wistar rats & Intubation to stomach & $\begin{array}{l}\text { Improved plasma lipid level and increased } \\
\text { plasma antioxidant activity }\end{array}$ & [94] \\
\hline & Rats & Oral administration & $\begin{array}{c}\text { No change in apolipoprotein A-1 level, lowered } \\
\text { apolipoprotein B, increase in erythrocyte } \\
\text { superoxide dismutase and catalase activity }\end{array}$ & {$[90]$} \\
\hline \multirow[t]{4}{*}{$\begin{array}{l}\text { Metabolic } \\
\text { syndrome }\end{array}$} & Rabbits & Oral administration & $\begin{array}{c}\text { Exhibit hepatic lipid droplets, cardiac } \\
\text { adipocytes infiltered and damage in endothelial } \\
\text { lining in aortic wall }\end{array}$ & [84] \\
\hline & Mice & Oral administration & $\begin{array}{l}\text { Lowered plasma total cholesterol level and } \\
\text { hepatic HMG-CoA reductase activity }\end{array}$ & [93] \\
\hline & Rats & Oral administration & Antithyroid and antioxidative activity & [123] \\
\hline & $\begin{array}{l}\text { Cholesterol } \\
\text { and 25-OH- } \\
\text { cholesterol- } \\
\text { treated HepG2 } \\
\text { cells, TNF-a- } \\
\text { treated human } \\
\text { umbilical vein } \\
\text { endothelial cells } \\
\text { (HUVECs) }\end{array}$ & Not mentioned in study & $\begin{array}{l}\text { Regulation of nuclear factor kappa-b (NF-kB) } \\
\text { and ERK signalling pathways, regulate the } \\
\text { cholesterol level and inflammatory responses }\end{array}$ & {$[87]$} \\
\hline Hyperthyroidism & Rats & Cell cultured with naringin & $\begin{array}{l}\text { Regulated hyperthyroidism by free radical } \\
\text { scavenging potential }\end{array}$ & [123] \\
\hline \multirow{3}{*}{ Asthma } & $\begin{array}{l}\text { Ovalbumin } \\
\text { induced } \\
\text { asthmatic mice }\end{array}$ & Oral administration & $\begin{array}{l}\text { Level of interleukin-4, INF gamma, T-bet, GATA } \\
\text { binding protein 3, Th1 and Th2 levels back to } \\
\text { normal, progression of asthma significantly inhibited }\end{array}$ & {$[98]$} \\
\hline & $\begin{array}{l}\text { Sprague-Dawley } \\
\text { rats exposed to } \\
\text { cigarette smoke }\end{array}$ & $\begin{array}{l}\text { Intragastrical } \\
\text { administration }\end{array}$ & $\begin{array}{c}\text { Inhibited the infiltration of inflammatory cells, } \\
\text { expansion of alveolar space and thickening of } \\
\text { bronchial walls }\end{array}$ & [99] \\
\hline & Mice & Oral administration & $\begin{array}{c}\text { Increased femoral bone mineral density on } \\
\text { distal and middle portions, suppression of } \\
\text { osteoclast formation }\end{array}$ & {$[103]$} \\
\hline \multirow[t]{2}{*}{$\begin{array}{l}\text { Osteoclastogenesis, } \\
\text { bone resorption, } \\
\text { osteolysis }\end{array}$} & $\begin{array}{c}\text { Murine } \\
\text { osteoblastic } \\
\text { MC3T3-E1 cells }\end{array}$ & Cell cultured with naringin & $\begin{array}{c}\text { Promote osteoprotegerin secretion in vitro by } \\
\text { osteoblasts and suppress bone loss }\end{array}$ & {$[105]$} \\
\hline & $\begin{array}{l}\text { Bone marrow } \\
\text { stromal cells }\end{array}$ & Cell cultured with naringin & $\begin{array}{c}\text { Upregulated osteogenesis related genes, } \\
\text { increased alkaline phosphatase activity and } \\
\text { accumulation of calcium in cell cultures. } \\
\text { Accumulation of Notch1 protein during } \\
\text { osteogenesis }\end{array}$ & {$[107]$} \\
\hline
\end{tabular}


dyslipidaemia and inflammation ${ }^{[81]}$. The $25 \%$ of the total world's adult population is suffering from metabolic syndrome. Increased diet, lesser physical activity, sedentary lifestyle and enhanced body mass index leads to enhanced occurrence of metabolic syndrome ${ }^{[81,82]}$. The potential of naringin to regulate metabolic disorders have been documented ${ }^{[72,83]}$.

\section{Signal transduction-mediated regulation:}

Naringin alleviated diet-induced metabolic syndrome in $\mathrm{C} 57 \mathrm{BL} / 6$ mice fed on fat-rich $\operatorname{diet}^{[84]}$. Activation of AMP activated protein kinase and insulin receptor substrate 1 blocked the activation of MAPKs pathways to improved lipogenesis and insulin resistance (fig. 3) ${ }^{[84]}$. Naringin reportedly, regulated insulin resistance, $\beta$-cell dysfunction, dyslipidaemia, liver and kidney damage by upregulating the PPAR $\gamma$ and heat shock proteins HSP-27 and HSP-72[85]. The potential of naringin to alter inflammatory cytokines expression and cholesterol metabolism via nuclear factor kappa-b $(\mathrm{NF}-\mathrm{\kappa B})$ and ERK signalling pathway regulation was responsible for cholesterol reduction in $25-\mathrm{OH}-$ cholesterol-treated HepG2 and TNF- $\alpha$-treated human umbilical vein endothelial cells ${ }^{[86]}$. Similarly, naringinmediated downregulation of chemokine C-X3-C motif ligand 1 (CX3CL1) and reduced ROS production was responsible for the antihyperglycemic potential of naringin ${ }^{[87]}$. Likewise, naringin-mediated regulation of heme oxygenase 1 via NF- $\mathrm{BB}$ and AMPK regulation was responsible for its antiinflammatory response during sepsis ${ }^{[88]}$.

\section{Regulation of diabetes, cardiovascular dysfunction and obesity:}

The ability of naringin to regulate glucose, fatty acid and cholesterol metabolism was responsible for its antidiabetic potential towards hyperglycaemic and extremely obese $\mathrm{C} 57 \mathrm{BL} / \mathrm{KsJ}$ mice as shown in fig. $4^{[89]}$. Naringin reportedly, enhanced the expression of angiopoietin- 1 and collagen- 1 promoting angiogenesis and inhibited apoptosis in the foot ulcers of diabetic rats $^{[90]}$. Likewise, naringin normalized cardiovascular dysfunction including systolic blood pressure and ventricular diastolic dysfunction of male Wistar rats fed on high carbohydrate and fat diet ${ }^{[91]}$.

\section{Regulation of hyperlipidaemia:}

The hypocholesterolemic potential of naringin contributes for its response against hyperlipidaemia. Naringin reduced the activity of acyl-coenzyme A, cholesterol acyltransferase and enhanced the activity of hepatic 3-hydroxy-3-methylglutaryl CoA reductase regulating the levels of low density lipoproteins, cholesterol and hepatic lipids, thus retarding aortic endothelium damage ${ }^{[83]}$. Likewise, naringin inhibited hepatic 3-hydroxy-3-methylglutaryl CoA reductase to regulate cholesterol accumulation of LDL receptor knockout LDLR-KO mice ${ }^{[92]}$. Likewise, rats fed with cholesterol were documented to maintain the plasma lipid levels and increase the plasma antioxidant activity on naringin exposure ${ }^{[93]}$. Further, naringin significantly showed antiplatelet effect on hyperlipidemic rabbits due to inhibition of P-selectin and platelet factor 4 accumulations $^{[94]}$. Likewise, HIV-1 nucleotide reverse transcriptase inhibitor-based hyperlipidaemia, apoptosis and oxidative stress of Wistar rats was potentially alleviated by naringin ${ }^{[95]}$.

\section{Naringin and immunity:}

Awassi male lambs pre-treated with antigen phytohemagglutinin (PHA) exposed to naringin showed accumulation of increased titres of antibody against PHA antigen compared to non-treated lambs. Further, the activity of antioxidant enzymes and weight of naringin-treated lambs was increased. Hence, naringin has enhanced the immune responses of lambs in addition to improvement in the other evaluation parameters $^{[96]}$.

\section{Antiasthmatic effect of naringin:}

Naringin significantly inhibited the ovalbumin-induced asthma by normalizing the levels of interleukin-4, INF gamma, T-bet, GATA binding protein 3 and cytokine Th1, Th2 ${ }^{[97]}$. The infiltration of inflammatory cells, expansion of alveolar space and thickening of bronchial walls induced by cigarette smoke was inhibited on naringin exposure ${ }^{[98]}$. Naringin, likewise regulated the pathological state of lungs, reduced interleukins and decreased lung airway hyper-responsiveness in guinea pigs $^{[97]}$.

\section{Promotion of bone formation and maintenance:}

Naringin potentially induces osteoblast differentiation and bone formation by inhibiting HMG-CoA reductase inhibitor ${ }^{[99]}$. Bone grafting with naringin-collagen matrix has shown significant formation of new bones in the defects ${ }^{[100]}$. Naringin enhanced protein accumulation, bone cell and alkaline phosphatase activity in in vitro culture of UMR 106 osteoblasts $^{[101]}$. Naringin reportedly, suppressed osteoclast formation 


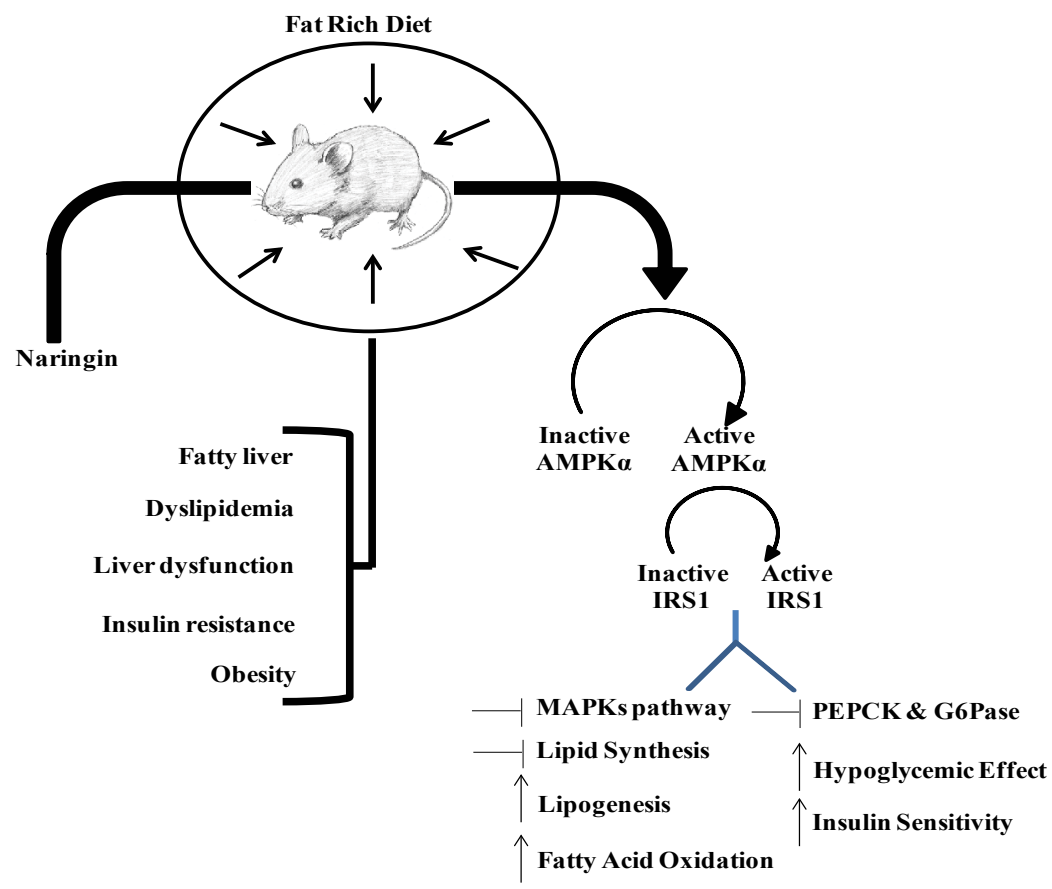

Fig. 3: Regulatory effect of naringin on metabolic syndrome

Mice fed with fat-rich diet showed metabolic syndrome characterised by fatty liver, dyslipidemia, liver dysfunction, insulin resistance and obesity. Naringin phosphorylated the AMP activated protein kinase (AMPKa) and insulin receptor substrate 1 (IRS1). Their activation led to inhibition of MAPK pathway and lipid biosynthesis. Simulatneously, the fatty acid oxidation, lipogenesis and insulin sensitivity was increased. Collectively, these alterations led to conteraction of metabolic syndrome, $(\uparrow)$ upregulation, $(\dashv)$ inhibition

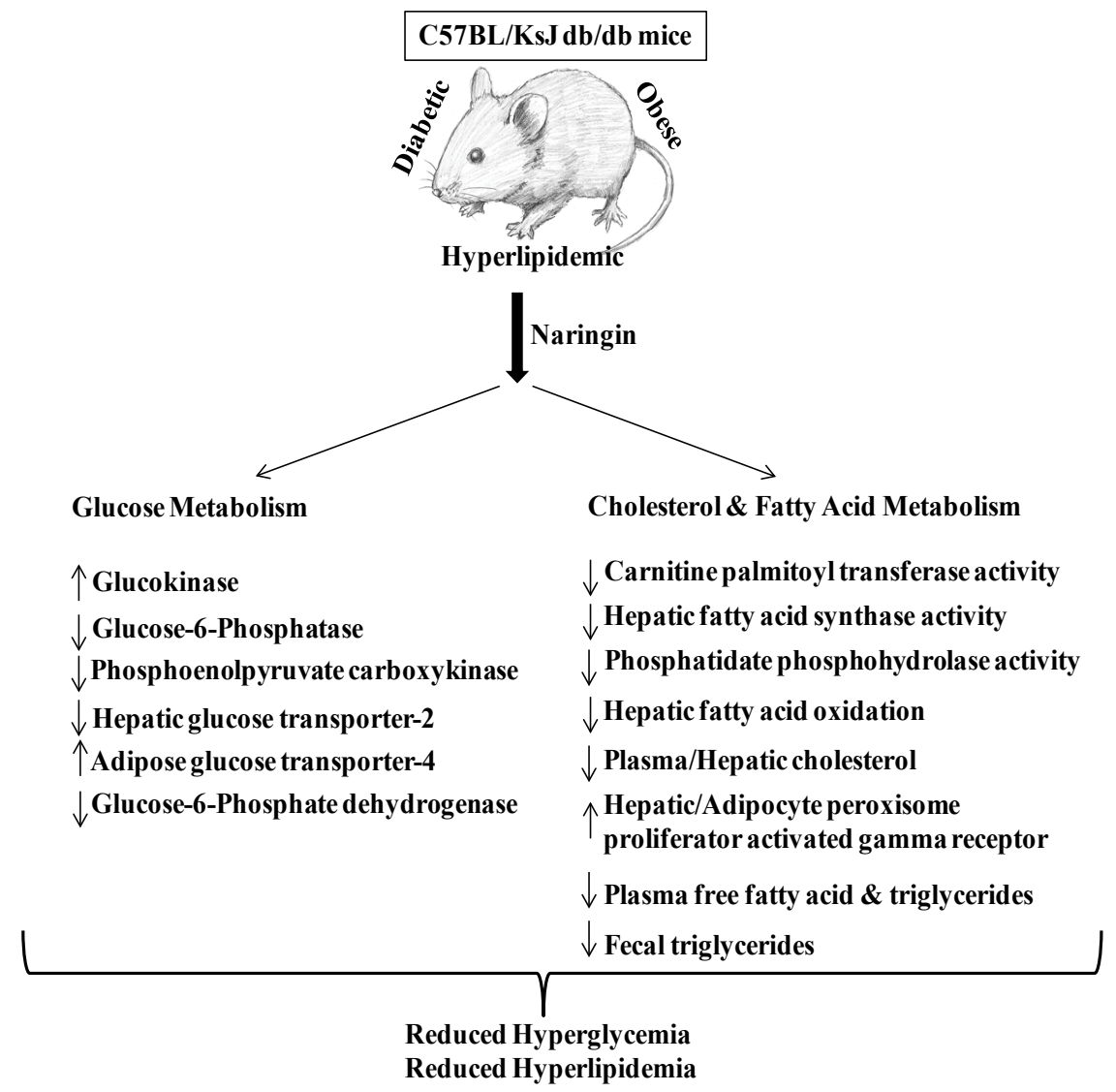

Fig. 4: Regulatory mechanism of naringin on diabetes

Naringin exposure variously affected the enzymes of lipid metabolism and glucose-regulating enzyme and reduced hyperglycemia and hyperlipidemia, $(\uparrow)$ upregulation, $(\downarrow)$ downregulation 
and increased the femoral bone mineral density in mice $^{[102]}$. Likewise, inhibition of bone resorption on naringin exposure has been documented ${ }^{[103,104]}$. Naringin-mediated regulation of NF- $\kappa \mathrm{B}$, ERK (fig. 5) and notch signalling pathway was responsible for its osteogenic activity ${ }^{[105,106]}$.

\section{Regulation of neurodegenerative disorders:}

The potential of naringin to regulate neurodegenerative disorders has been revealed ${ }^{[107-110]}$. Naringin reportedly upregulated brain-derived neurotrophic and vascular endothelial growth factor followed by inhibition of neural apoptosis to alleviate spinal cord injury ${ }^{[108]}$. Role of naringin on the prevention of Parkinson's disease has also been documented ${ }^{[109]}$. Further, naringin enhanced glia-derived neurotrophic factor and suppressed TNF- $\alpha$ to regulate the symptoms of Parkinson disease in rat models ${ }^{[110]}$.

\section{Alleviation of metal and chemical compound- induced toxicity:}

Naringin significantly alleviates metal as well as chemical compound-induced toxicity. Naringin stimulated the antioxidant system to counteract nickelinduced nephrotoxicity and hepatotoxicity ${ }^{[11,112]}$. The concomitant exposure of naringin with mercuric chloride potentially chelated the metal ions to ameliorate induced toxicity ${ }^{[113]}$. Likewise, toxicity induced by metallic chlorides and arsenites were reportedly alleviated on naringin exposure ${ }^{[114-116]}$. Neuroprotective potential of naringin to suppress insecticide deltamethrin-induced toxicity has also been reported $^{[117]}$. Similarly, alleviation of cardiotoxicity, neurotoxicity and renal-hepatic toxicity induced by doxorubicin, bleomycin, acetaminophen and methotrexate on naringin exposure are reported ${ }^{[118-122]}$.

\section{Antithyroid potential:}

Hyperthyroidism induced by L-thyroxine (L-T4) in rats has been documented to be regulated by the exposure of naringin ${ }^{[122]}$. The free radical scavenging potential of flavonoids, naringin, rutin and hesperidin regulated hyperthyroidism without any risk of hepatotoxicity ${ }^{[123]}$.

Hence in view of the reports documenting the multifarious medicinal applications of naringin,


Fig. 5: Regulatory effect of naringin on bone resoprtion Osteoclast activation leads to bone resorption leading to bone breakage. Binding of RANK with RANL leads to activation of NF$\kappa B$ and ERK and promotes osteoclast formation. Naringin exposure inhibits the binding of RANK with RANL thus, inhibiting the downstream activations and counteracting the osteoclast formation 
naringin containing food products can be recommended as a probable supplementation to the existing treatments for various disorders as well as maintain human health. Naringin could be used as a natural therapeutic supplement along the treatment line to alleviate several medical disorders and alterations. Studies have reported the underlying mechanism of naringin action on animal cell lines. However, detailed understanding of molecular and biochemical aspects of naringin exposure can extrapolate its medicinal applications on humans as well. Further, better understanding of the phenylpropanoid pathway will reveal the scope of synthesis and regulation of naringin in vitro as well as in vivo.

\section{Acknowledgements:}

PS acknowledges DST for research fellowship. PG is very thankful to DST SERB, GOI for financial support in the form of Project YSS/2015/000719.

\section{Conflicts of interest:}

The authors declare no conflict of interest.

\section{REFERENCES}

1. Pietta PG. Flavonoids as Antioxidants. J Nat Prod 2000;63:1035-42.

2. Ross JA, Kasum CM. Dietary Flavonoid: Bioavailability, Metabolic Effects, and Safety. Annu Rev Nutr 2002;22:19-34.

3. Kelly EH, Anthony RT, Dennis JB. Flavonoid antioxidants:chemistry, metabolism and structure-activity relationships. J Nutr Biochem 2002;13:572-84.

4. Nijveldt RJ, van Nood E, van Hoorn DE, Boelens PG, van Norren K, van Leeuwen PA. Flavonoids: a review of probable mechanisms of action and potential applications. Am J Clin Nutr 2001;74:418-25.

5. Galeotti F, Barile E, Curir P, Dolci M, Lanzotti V. Flavonoids from carnation (Dianthus caryophyllus) and their antifungal activity. Phytochem Lett 2008:1;44-8.

6. Prochazkova D, Bousova I, Wilhelmova N. Antioxidant and prooxidant properties of flavonoids. Fitoterapia 2011;82:51323.

7. Subarnas A, Wagner H. Analgesic and anti-inflammatory activity of the proanthocyanidins shellegueain A from Polypodium feei. Phytomedicine 2000;7:401-5.

8. Calderone V, Chericoni S, Martinelli C, Testai L, Nardi A, Morelli I, et al. Vasorelaxing effects of flavonoids: investigation on the possible involvement of potassium channels. Naunyn Schmiedebergs Arch Pharmacol 2004;370:290-8.

9. Weber JM, Ruzindana-Umunyana A, Imbeault L, Sircar S. Inhibition of adenovirus infection and adenain by green tea catechins. Antiviral Res 2003;58:167-73.

10. Widlansky ME, Duffy SJ, Hamburg NM, Gokce N, Warden BA, Wiseman S, et al. Effects of black tea consumption on plasma catechins and markers of oxidative stress and inflammation in patients with coronary artery disease. Free Radic Biol Med 2005;38:499-506.
11. Alvesalo J, Vuorela H, Tammela P, Leinonen M, Saikku P, Vuorela P. Inhibitory effect of dietary phenolic compounds on Chlamydia pneumoniae in cell cultures. Biochem. Pharmaco 2006;71:735-41.

12. Mladenka P, Zatloukalova L, Filipsky T, Hrdina R. Cardiovascular effects of flavonoids are not caused only by direct antioxidant activity. Free Radic Biol Med 2010;15:96375 .

13. Wang Y, Ho CT. Metabolism of Flavonoids. In: Yoshikawa T, editor. Food Factors for Health Promotion. Basel, Switzerland: Forum of Nutrition Home - Karger Publishers; 2009. p. 64-74.

14. Tiller SA, Parry AD, Edwards R. Changes in the accumulation of flavonoid and isoflavonoid conjugates associated with plant age and nodulation in alfalfa (Medicago sativa). Physiol Plant 1994;91:27-36.

15. Lavola A. Accumulation of flavonoids and related compounds in birch induced by UV-B irradiance. Tree Physiol 1998;18:538.

16. Mathesius U. Flavonoids induced in cells undergoing nodule organogenesis in white clover are regulators of auxin breakdown by peroxidase. J Exp Bot 2010;52:419-26.

17. Braidot E, Zancani M, Petrussa E, Peresson C, Bertolini A, Patui S, et al. Transport and accumulation of flavonoids in grapevine (Vitis vinifera L.). Plant Signal Behav 2008;3:62632.

18. Quattrocchio F, Baudry A, Lepiniec L, Gotewold E. The regulation of flavonoid biosynthesis. In: Grotewold E, editor. The science of flavonoids. Columbus, $\mathrm{OH}$ : The Ohio State University, 2006. p. 97-122.

19. Tripoli E, Guardia ML, Giammanco S, Majo DD, Giammanco M. Citrus flavonoids: Molecular structure, biological activity and nutritional properties: A review. Food Chem 2007;104:466-79.

20. Ho PC, Saville DJ, Wanwimolruk S. Inhibition of human CYP3A4 activity by grapefruit flavonoids, furanocoumarins and related compounds. J Pharm Sci 2001;4:217-27.

21. Guleria P, Kumar V. Understanding the phenylpropanoid pathway for agronomical and nutritional improvement of mungbean. J Hortic Sci Biotechnol 2017;92:335-48.

22. Wang $\mathrm{C}$, Zhi $\mathrm{S}$, Liu $\mathrm{C}, \mathrm{Xu} \mathrm{F}$, Zhao A, Wang $\mathrm{X}$, et al. Characterization and functional analysis of 4-coumarate:coa ligase genes in mulberry. PLoS One 2016a;11:e0155814.

23. Winkel-Shirley B. Flavonoid Biosynthesis. A Colorful Model for Genetics, Biochemistry, Cell Biology, and Biotechnology. Plant Physiol 2001;126:485-93.

24. Zeng S, Liu Y, Zou C, Huang W, Wang Y. Cloning and characterization of phenylalanine ammonia-lyase in medicinal Epimedium species. Plant Cell Tiss Organ Cult 2013;113:25767.

25. Zhu Q, Xie X, Lin H, Sui S, Shen R, Yang Z, et al. Isolation and Functional Characterization of a Phenylalanine Ammonia-Lyase Gene (SsPAL1) from Coleus (Solenostemon scutellarioides (L.) Codd). Molecules 2015;20:16833-51.

26. Thiyagarajan K, Vitali F, Tolaini V, Galeffi P, Cantale C, Vikram $\mathrm{P}$, et al. Genomic Characterization of Phenylalanine Ammonia Lyase Gene in Buckwheat. PLoS One 2016;11:e151187.

27. Sangsil $P$, Nualsri $C$, Woraathasin N, Nakkanong $K$. Characterization of the phenylalanine ammonia lyase gene from the rubber tree (Hevea brasiliensis Müll. Arg.) and differential response during Rigidoporus microporus infection. J Plant Protect Res 2016;56:380-88.

28. Kim DS, Hwang BK. An important role of the pepper 
phenylalanine ammonia-lyase gene (PAL1) in salicylic aciddependent signalling of the defence response to microbial pathogens. J Exp Bot 2014;65:2295-306.

29. Tonnessen BW, Manosalva P, Lang JM, Baraoidan M, Bordeos A, Mauleon R, et al. Rice phenylalanine ammonia lyase gene OsPAL4 is associated with broad spectrum disease resistance. Plant Mol Biol 2015;87:273-86.

30. Jong F, Hanley SJ, Beale MH, Karp A. Characterisation of the willow phenylalanine ammonia-lyase (PAL) gene family reveals expression differences compared with poplar. Phytochemistry 2015;117:90-7.

31. Wang Z, Li JY, Jia CH, Li JP, Xu BY, Jin ZQ. Molecular cloning and expression of four phenylalanine ammonia lyase genes from banana interacting with Fusarium oxysporum. Biol Plant 2016b;60:459-68.

32. Goldson-Barnaby A, Scaman CH. Purification and characterization of phenylalanine ammonia lyase from Trichosporon cutaneum. Enzyme Res 2013;2013:1-6.

33. Hyun MW, Yun YH, Kim JY, Kim SH. Fungal and plant phenylalanine ammonia-lyase. Mycobiology 2011;39:257-65.

34. Ro DK, Mah N, Ellis BE, Douglas CJ. Functional characterization and subcellular localization of poplar (Populus trichocarpa x Populus deltoides) cinnamate 4-hydroxylase. Plant Physiol 2001;126:317-329.

35. Hallahan DL, Cheriton AK, Hyde R, Forde BG. Plant cytochrome P450 and agricultural biotechnology. Biochem Soc Trans 1993;21:10681073.

36. Liu F, Chen JR, Tang YH, Chang HT, Yuan YM, Guo Q. Isolation and characterization of cinnamate 4-hydroxylase gene from cultivated ramie (Boehmeria nivea), Biotechnol Biotechnol Equip 2018a;32:324-31.

37. Cheng S, Yan J, Meng X, Zhang W, Liao Y, Ye J, et al. Characterization and expression patterns of a cinnamate4-hydroxylase gene involved in lignin biosynthesis and in response to various stresses and hormonal treatments in Ginkgo biloba. Acta Physiol Plant 2018;40:7.

38. Liu XY, Yu HN, Gao S, Gao S, Wu YF, Cheng AX, et al. The isolation and functional characterization of three liverwort genes encoding cinnamate 4-hydroxylase. Plant Physiol Biochem 2017b;117:42-50.

39. Xia J, Liu Y, Yao S, Li M, Zhu M, Huang $\mathrm{K}$, et al. characterization and expression profiling of camellia sinensis cinnamate 4-hydroxylase genes in phenylpropanoid pathways. Genes 2017;8:193.

40. Wang A, Zhu M, Luo Y, Liu Y, Li R, Kou M, et al. A sweet potato cinnamate 4-hydroxylase gene, IbC4H, increases phenolics content and enhances drought tolerance in tobacco. Acta Physiol Plant 2017a;39:276.

41. Li W, Yang L, Jiang L, Zhang G, Luo Y. Molecular cloning and functional characterization of a cinnamate 4-hydroxylaseencoding gene from Camptotheca acuminata. Acta Physiol Plant 2016;38:256.

42. Chen L, Guo H, Lin Y, Wu Y, Cheng H. Molecular cloning and characterization of the cinnamate 4-hydroxylase gene from Eupatorium adenophorum. Weed Biol Manag 2014;14:16777.

43. Heath R, McInnes R, Lidgett A, Huxley H, Lynch D, Jones $\mathrm{E}$, et al. Isolation and characterisation of three 4-coumarate: CoA-ligase homologue cDNAs from perennial ryegrass (Lolium perenne). J Plant Physiol 2002;159:773-9.

44. Xu H, Park NI, Li X, Kim YK, Lee SY, Park SU. Molecular cloning and characterization of phenylalanine ammonia- lyase, cinnamate 4-hydroxylase and genes involved in flavone biosynthesis in Scutellaria baicalensis. Bioresour Technol 2010;101:9715-22.

45. Liu T, Yao R, Zhao Y, Xu S, Huang C, Luo J, et al. Cloning, Functional Characterization and Site-Directed Mutagenesis of 4-Coumarate: Coenzyme A Ligase (4CL) Involved in Coumarin Biosynthesis in Peucedanum praeruptorum Dunn. Front Plant Sci 2017a;8:4.

46. Gao S, Yu HN, Xu RX, Cheng AX, Lou HX. Cloning and functional characterization of a 4-coumarate CoA ligase from liverwort Plagiochasma appendiculatum. Phytochemistry 2015;111:48-58.

47. Li Y, Kim JI, Pysh L, Chapple C. Four Isoforms of Arabidopsis 4-Coumarate:CoA Ligase Have Overlapping yet Distinct Roles in Phenylpropanoid Metabolism. Plant Physiol 2015;169:2409-21.

48. Wang C, Zhi S, Liu C, Xu F, Zhao A, Wang X, et al. Isolation and characterization of a novel chalcone synthase gene family from mulberry. Plant Physiol Biochem 2017b;115:107-18.

49. Chen S, Pan X, Li Y, Cui L, Zhang Y, Zhang Z, et al. Identification and characterization of chalcone synthase gene family members in Nicotiana tabacum. J Plant Growth Regul 2017;36:374-84.

50. Yahyaa M, Ali S, Davidovich-Rikanati R, Ibdah M, Shachtier A, Eyal Y, et al. Characterization of three chalcone synthase-like genes from apple (Malus x domestica Borkh). Phytochemistry 2017;140:125-33.

51. Wang Y, Dou Y, Wang R, Guan X, Hua Z, Zheng J. Molecular characterization and functional analysis of chalcone synthase from Syringa oblata Lindl. in the flavonoid biosynthetic pathway. Gene 2017c;635:16-23.

52. Deng X, Bashandy H, Ainasoja M, Kontturi J, Pietiäinen J, Laitinen RA, et al. Functional diversification of duplicated chalcone synthase genes in anthocyanin biosynthesis of Gerbera hybrida. New Phytol 2014;201:1469-83.

53. Dong C, Yu AQ, Wang ML, Zheng XW, Diao Y, Xie KQ, et al. Identification and characterization of chalcone synthase cDNAs (NnCHS) from Nelumbo nucifera. Cell Mol Biol (Noisy-le-grand) 2015;61:112-17.

54. Morita Y, Takagi K, Fukuchi-Mizutani M, Ishiguro K, Tanaka $\mathrm{Y}$, Nitasaka E, et al. A chalcone isomerase-like protein enhances flavonoid production and flower pigmentation. Plant J 2014;78:294-304.

55. Zhou L, Wang Y, Ren L, Shi Q, Zheng B, Miao K, et al. Overexpression of Ps-CHI1, a homologue of the chalcone isomerase gene from tree peony (Paeonia suffruticosa), reduces the intensity of flower pigmentation in transgenic tobacco. Plant Cell Tiss Organ Cult 2014;116:285-95.

56. Park SH, Lee CW, Cho SM, Lee H, Park H, Lee J, et al. Crystal structure and enzymatic properties of chalcone isomerase from the Antarctic vascular plant Deschampsia antarctica Desv. PLoS One 2018; 13:e0192415.

57. He F, Pan Y. Purification and characterization of chalcone isomerase from fresh-cut Chinese water-chestnut. Food Sci Technol 2017;79:402-9.

58. Kang JH, McRoberts J, Shi F, Moreno E, Jones AD, Howe GA. The flavonoid biosynthetic enzyme chalcone isomerase modulates terpenoid production in glandular trichomes of tomato. Plant Physiol 2014;164:1161-74.

59. Fujino N, Yamazaki $\mathrm{T}$, Li Y. cDNA cloning and characterization of chalcone isomerase-fold proteins from 
snapdragon (Antirrhinum majus L.) flowers. Plant Biotechnol 2014;31:105-14.

60. Jones P, Vogt T. Glycosyltransferases in secondary plant metabolism: tranquilizers and stimulant controllers. Planta 2001;213:164-74.

61. Vogt T, Jones P. Glycosyltransferases in plant natural product synthesis: characterization of a supergene family. Trends Plant Sci 2000;5:38066.

62. Liu X, Lin C, Ma X, Tan Y, Wang J, Zeng M. Functional Characterization of a Flavonoid Glycosyltransferase in Sweet Orange (Citrus sinensis). Front Plant Sci 2018b;9:166.

63. Sun W, Liang L, Meng X, Li Y, Gao F, Liu X, et al. Biochemical and molecular characterization of a flavonoid 3-o-glycosyltransferase responsible for anthocyanins and flavonols biosynthesis in Freesia hybrida. Front Plant Sci 2016;7:410.

64. Trapero A, Ahrazem O, Rubio-Moraga A, Jimeno ML, Gómez MD, Gómez-Gómez L. Characterization of a Glucosyltransferase Enzyme Involved in the Formation of Kaempferol and Quercetin Sophorosides in Crocus sativus. Plant Physiol 2012;159:1335-54.

65. Bharti S, Rani N, Krishnamurthy B, Arya DS. Preclinical evidence for the pharmacological actions of naringin. Planta Med 2014;80:437-51.

66. Schindler R, Mentlein R. Flavonoids and vitamin E reduce the release of the angiogenic peptide vascular endothelial growth factor from human tumor cells. J Nutr 2006;136:1477-82.

67. Pham-Huy LA, He H, Pham-Huy C. Free radicals, antioxidants in disease and health. Int J Biomed Sci 2008;4:89-96.

68. Gaur V, Aggarwal A, Kumar A. Protective effect of naringin against ischemic reperfusion cerebral injury: Possible neurobehavioral, biochemical and cellular alteration in rat brain. Eur J Pharmacol 2009;616:147-54.

69. Feng J, Chen X, Lu S, Li W, Yang D, Su W, et al. Naringin attenuates cerebral ischemia-reperfusion injury through inhibiting peroxynitrite-mediated mitophagy activation. Mol Neurobiol 2018;55:9029-42.

70. Singh D, Chopra K. The effect of naringin, a bioflavonoid on ischemia-reperfusion induced renal injury in rats. Pharmacol Res 2004;50:187-93.

71. Isik A, Peker K, Gursul C, Sayar I, Firat D, Yilmaz I, et al. The effect of ozone and naringin on intestinal ischemia/reperfusion injury in an experimental model. Int J Surg 2015;21:38-44.

72. Rajadurai M, Prince PSM. Preventive effect of naringin on lipids, lipoproteins and lipid metabolic enzymes in isoproterenol-induced myocardial infarction in Wistar rats. J Biochem Mol Toxicol 2006;20:191-7.

73. Rajadurai M, Prince PSM. Naringin ameliorates mitochondrial lipid peroxides, antioxidants and lipids in isoproterenolinduced myocardial infarction in Wistar rats. Phytother Res 2009;23:358-62.

74. Gursul C, Ekinci Akdemir FN, Akkoyun T, Can İ, Gül M, Gülçin İ. Protective effect of Naringin on experimental hindlimb ischemia/reperfusion injury in rats. J Enzyme Inhib Med Chem 2016;31(sup1):56-61.

75. Li H, Yang B, Huang J, Xiang T, Yin X, Wan J, et al. Naringin inhibits growth potential of human triple-negative breast cancer cells by targeting $\beta$-catenin signalling pathway. Toxicol Lett 2013;220:219-28.

76. Kim DI, Lee SJ, Lee SB, Park K, Kim WJ, Moon SK. Requirement for Ras/Raf/ERK pathway in naringin-induced
G1-cell-cycle arrest via p21WAF1 expression. Carcinogenesis 2008;29:1701-9.

77. Camargo CA, Gomes-Marcondes MC, Wutzki NC, Aoyama H. Naringin inhibits tumor growth and reduces interleukin-6 and tumor necrosis factor $\alpha$ levels in rats with Walker 256 carcinosarcoma. Anticancer Res 2012;32:129-33.

78. Yoshinaga A, Kajiya N, Oishi K, Kamada Y, Ikeda A, Chigwechokha PK, et al. NEU3 inhibitory effect of naringin suppresses cancer cell growth by attenuation of EGFR signaling through GM3 ganglioside accumulation. Eur J Pharmacol 2016;782:21-9.

79. Xie D, Yuan P, Wang D, Jin H, Chen H. Effects of naringin on the expression of miR-19b and cell apoptosis in human hepatocellular carcinoma. Oncol Lett 2017;14:1455-59.

80. Garcia JP, Lakshmi BA, Kim S. Potenial anticancer applications on the novel naringin-based ruthenium (II) complex. 3 Biotech 2019;9:181.

81. Kaur J. A comprehensive review on metabolic syndrome. Cardiol Res Pract 2014;21:228.

82. Cameron AJ, Shaw JE, Zimmet PZ. The metabolic syndrome: prevalence in worldwide populations. Endocrinol Metab Clin North Am 2004;33:351-75.

83. Jeon SM, Park YB, Choi MS. Antihypercholesterolemic property of naringin alters plasma and tissue lipids, cholesterolregulating enzymes, fecal sterol and tissue morphology in rabbits. Clin Nutr 2004;23:1025-34.

84. Pu P, Gao DM, Mohamed S, Chen J, Zhang J, Zhou XY, et al. Naringin ameliorates metabolic syndrome by activating AMP-activated protein kinase in mice fed a high-fat diet. Arch Biochem Biophys 2012;518:61-70.

85. Sharma AK, Bharti S, Ojha S, Bhatia J, Kumar N, Ray R, et al. Up-regulation of PPAR $\gamma$, heat shock protein-27 and -72 by naringin attenuates insulin resistance, $\beta$-cell dysfunction, hepatic steatosis and kidney damage in a rat model of type 2 diabetes. Br J Nutr 2011;106:1713-23.

86. Liang J, Wang C, Peng J, Li W, Jin Y, Liu Q, et al. Naringin regulates cholesterol homeostasis and inhibits inflammation via modulating $\mathrm{NF}-\kappa \mathrm{B}$ and ERK signaling pathways in vitro. Pharmazie 2016;71:101-8.

87. Li G, Xu Y, Sheng X, Liu H, Guo J, Wang J, et al. Naringin protects against high glucose-induced human endothelial cell injury via antioxidation and CX3CL1 downregulation. Cell Physiol Biochem 2017;42:2540-51.

88. Gil M, Kim YK, Hong SB, Lee KJ. Naringin decreases TNF- $\alpha$ and HMGB1 release from LPS-stimulated macrophages and improves survival in a CLP-induced sepsis mice. PLoS One 2016;11:e0164186.

89. Jung UJ, Lee MK, Park YB, Kang MA, Choi MS. Effect of citrus flavonoids on lipid metabolism and glucose-regulating enzyme mRNA levels in type-2 diabetic mice. Int J Biochem Cell Biol 2006;38:1134-45.

90. Kandhare AD, Ghosh P, Bodhankar SL. Naringin, a flavanone glycoside, promotes angiogenesis and inhibits endothelial apoptosis through modulation of inflammatory and growth factor expression in diabetic foot ulcer in rats. Chem-Biol Interact 2014;219:101-12.

91. Alam MA, Kauter K, Brown L. Naringin improves dietinduced cardiovascular dysfunction and obesity in high carbohydrate, high fat diet-fed rats. Nutr 2013;5:637-50.

92. Kim HJ, Oh GT, Park YB, Lee MK, Seo HJ, Choi MS. Naringin alters the cholesterol biosynthesis and antioxidant 
enzyme activities in LDL receptor-knockout mice under cholesterol fed condition. Life Sci 2004;74:1621-34.

93. Gorinstein S, Leontowicz H, Leontowicz M, Krzeminski $\mathrm{R}$, Gralak M, Delgado-Licon E, et al. Changes in plasma lipid and antioxidant activity in rats as a result of naringin and red grapefruit supplementation. J Agric Food Chem 2005;53:3223-8.

94. Xiao Y, Li LL, Wang YY, Guo JJ, Xu WP, Wang YY, et al. Naringin administration inhibits platelet aggregation and release by reducing blood cholesterol levels and the cytosolic free calcium concentration in hyperlipidemic rabbits. Exp Ther Med 2014;8:968-72.

95. Adebiyi OO, Adebiyi OA, Owira PM. Naringin reverses hepatocyte apoptosis and oxidative stress associated with HIV-1 nucleotide reverse transcriptase inhibitors-induced metabolic complications. Nutrients 2015;7:10352-68.

96. Alhidary IA, Abdelrahman MM. Effects of naringin supplementation on productive performance, antioxidant status and immune response in heat-stressed lambs. Small Ruminant Res 2016;138:31-6.

97. Guihua X, Shuyin L, Jinliang G, Wang S. Naringin protects ovalbumin-induced airway inflammation in a mouse model of asthma. Inflammation 2016;39:891-9.

98. Nie YC, Wu H, Li PB, Luo YL, Long K, Xie LM, et al. Anti-inflammatory effects of naringin in chronic pulmonary neutrophilic inflammation in cigarette smoke-exposed rats. J Med Food 2012;15:894-900.

99. Schlienger RG, Meier CR. HMG-CoA reductase inhibitors in osteoporosis: Do they reduce the risk of fracture? Drugs Aging 2003;20:321-36.

100. Wong RW, Rabie AB. Effect of naringin collagen graft on bone formation. Biomaterials 2006b;27:1824-31.

101. Wong RW, Rabie AB. Effect of naringin on bone cells. J Orthop Res 2006a;24:2045-50.

102. Hirata M, Matsumoto C, Takita M, Miyaura C, Inada M. Naringin suppresses osteoclast formation and enhances bone mass in mice. J Health Sci 2009;55:463-7.

103. Li N, Xu Z, Wooley PH, Zhang J, Yang SY. Therapeutic potentials of naringin on polymethylmethacrylate induced osteoclastogenesis and osteolysis, in vitro and in vivo assessments. Drug Des Devel Ther 2014;8:1-11.

104. Xu T, Wang L, Tao Y, Ji Y, Deng F, Wu XH. The Function of Naringin in Inducing Secretion of Osteoprotegerin and Inhibiting Formation of Osteoclasts. Evid Based Complement Altern Med 2016;22;1-7.

105. Ang ESM, Yang X, Chen H, Liu Q, Zheng MH, Xu J. Naringin abrogates osteoclastogenesis and bone resorption via the inhibition of RANKL-induced NF-jB and ERK activation. FEBS Lett 2011;585:2755-62.

106. Yu GY, Zheng GZ, Chang B, Hu QX, Lin FX, Liu DZ, et al. Naringin Stimulates Osteogenic Differentiation of Rat Bone Marrow Stromal Cells via Activation of the Notch Signaling Pathway. Stem Cells Int 2016;26;1-8.

107. Golechha M, Chaudhry U, Bhatia J, Saluja D, Arya DS. Naringin protects against kainic acid-induced status epilepticus in rats: evidence for an antioxidant, anti-inflammatory and neuroprotective intervention. Biol Pharm Bull 2011;34:360-5.

108. Rong W, Wang J, Liu X, Jiang L, Wei F, Hu X, et al. Naringin treatment improves functional recovery by increasing BDNF and VEGF expression, inhibiting neuronal apoptosis after spinal cord injury. Neurochem Res 2012;37:1615-23.

109. Deumens R, Blokland A, Prickaerts J. Modeling Parkinson's disease in rats: an evaluation of 6-OHDA lesions of the nigrostriatal pathway. Exp Neurol 2002;175:303-17.

110. Leem E, Nam JH, Jeon MT, Shin WH, Won SY, Parkv SJ, et $a l$. Naringin protects the nigrostriatal dopaminergic projection through induction of GDNF in a neurotoxin model of Parkinson's disease. J Nutr Biochem 2014;25:801-6.

111. Amudha K, Pari L. Beneficial role of naringin, a flavonoid on nickel induced nephrotoxicity in rats. Chem Biol Interact 2011;193:57-64.

112. Pari L, Amudha K. Hepatoprotective role of naringin on nickel-induced toxicity in male Wistar rats. Eur J Pharm 2011;650:364-370.

113. Harisa GT, Mariee AD, Abo-Salem OM, Attiaa SM. Erythrocyte nitric oxide synthase as a surrogate marker for mercury-induced vascular damage: The modulatory effects of naringin. Environment Toxicol 2104;291:314-1322.

114. Jamalan M, Ghaffari MA, Hoseinzadeh P, Hashemitabar M, Zeinali M. Human sperm quality and metal toxicants: protective effects of some flavonoids on male reproductive function. Int J Fertil Steril 2016;10:215-23.

115. Adil M, Kandhare AD, Ghosh P, Bodhankar SL. Sodium arsenite-induced myocardial bruise in rats: Ameliorative effect of naringin via TGF- $\beta / \mathrm{Smad}$ and Nrf/HO pathways. Chem Biol Interact 2016a;253:66-77.

116. Adil M, Kandhare AD, Visnagri A, Bodhankar SL. Naringin ameliorates sodium arsenite-induced renal and hepatic toxicity in rats: decisive role of KIM-1, Caspase-3, TGF- $\beta$, and TNF- $\alpha$. Ren Fail 2015;37:1396-407.

117. Mani VM, Asha S, Sadiq AMM. Pyrethroid deltamethrininduced developmental neurodegenerative cerebral injury and ameliorating effect of dietary glycoside naringin in male Wistar rats. Biomed Aging Pathol 2014;4:1-8.

118. Kwatra M, Kumar V, Jangra A, Mishra M, Ahmed S, Ghosh $\mathrm{P}$, et al. Ameliorative effect of naringin against doxorubicininduced acute cardiac toxicity in rats. Pharm Biol 2016;54:63747.

119. Ramalingayya GV, Nayak PG, Shenoy RR, Malik SB, Gourishetti K, Hussain SM, et al. Naringin ameliorates doxorubicin-induced neurotoxicity in vitro and cognitive dysfunction in vivo. Phcog Mag 2018;197-207.

120. Turgut NH, Kara H, Elagoz S, Deveci K, Gungor H, Arslanbas E. The protective effect of naringin against bleomycin-induced pulmonary fibrosis in Wistar rats. Pulm 2016;2016:1-12.

121. Adil M, Kandhare AD, Ghosh P, Venkata S, Raygude KS, Bodhankar SL. Ameliorative effect of naringin in acetaminophen-induced hepatic and renal toxicity in laboratory rats: role of FXR and KIM-1. Ren Fail 2016b;38:1007-20.

122. Kandemir FM, Kucukler S, Caglayan C, Gur C, Batil AA, Gülçin I. Therapeutic effects of silymarin and naringin on methotrexate-induced nephrotoxicity in rats: Biochemical evaluation of anti-inflammatory, antiapoptotic, and antiautophagic properties. J Food Biochem 2017;41:e12398

123. Panda S, Kar A. Antithyroid effects of naringin, hesperidin and rutin in 1-T4 induced hyperthyroid rats: Possible mediation through 5'DI activity. Pharmacol Rep 2014;66:1092-9. 